\title{
Relationship Changes In IT Offshoring
}

\author{
Jeremy St. John, Texas A\&M University-Commerce, USA \\ Richard Vedder, University of North Texas, USA \\ Carl S. Guynes, University of North Texas, USA
}

\begin{abstract}
As the sheer volume of IT being offshored continues to grow, other changes are occurring. The type of IT work being offshored is expanding as more sophisticated vendors and technologies make it feasible for new, often more complicated, IT work to be offshored. Information Technology (IT) is continually improving, transforming formerly non-offshorable personal tasks into offshorable impersonal tasks. The relationships between clients and their offshore vendors have been changing, most obviously in the sheer volume of offshoring being undertaken. To gain a better picture of offshoring, it is necessary to examine these changing aspects.
\end{abstract}

Keywords: Offshoring Relationships; Outsourcing; Client-Vendor Trust

\section{INTRODUCTION}

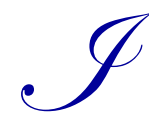
nformation Systems outsourcing began in the 1960s when EDS began making arrangements with other companies to handle their data processing needs. However, Kodak is generally credited with being the first large company to outsource IT on a grand scale in 1989 (Rajkumar \& Mani, 2001). Because other large companies followed the example set by Kodak, the term "Kodak effect" was coined to describe the phenomenon of modern IT outsourcing.

As the sheer volume of IT being offshored continues to grow, other changes are occurring. The type of IT work being offshored is expanding as more sophisticated vendors and technologies make it feasible for new, often more complicated IT work to be offshored. Bandwidth continues to increase while costs continue to decrease, reducing barriers to offshoring and changing the nature of what can be offshored. Information Technology (IT) is continually improving, transforming formerly non-offshorable personal tasks into offshorable impersonal tasks. Vendor countries, such as India and China, continue to modernize and gear their infrastructure and workforce toward offshoring. There has been an increase in the complexity, sensitivity and critical nature of the work being offshored, partly because of the billions of dollars in potential cost savings as well as a widespread failure of offshoring to "deliver as promised" continues. Blinder, writing in Foreign Affairs (2006), describes the upcoming changes that the offshoring phenomenon will bring as nothing less than the third industrial revolution that will transform society beyond recognition.

Offshoring characteristics have been changing over time. The relationships between clients and their offshore vendors have been changing, most obviously in the sheer volume of offshoring being undertaken. Additionally, the critical success factors of offshoring have changed over time. To gain a full picture of offshoring, it is necessary to examine these changing aspects as well as the theories used to study offshoring, which have also been changing.

\section{OFFSHORING RELATIONSHIP ISSUES}

A prior study has shown that more than $50 \%$ of outsourcing partnerships fail, not because of bad contracts or financial issues, but due to relationship issues (Rajkumar \& Mani, 2001). Offshoring relationships are dynamic and evolve over time due to changes in the external environment and the client's internal requirements. These changes include increasing wages for offshore employees and more competition between vendors for clients and clients for vendors. Additionally, technology improvements are allowing the offshoring of more work and more types of work. Clients are requiring more complex, value-added work of a strategic rather than cost savings nature. These changes require closer, more complex relationships between client and vendor (Kaiser \& Hawk, 2004). 
According to several studies, half of the organizations that have shifted processes offshore have failed to generate the expected financial benefits (Aron \& Singh, 2005). Software developers in India earn much less than their counterparts in the USA. The opportunity for cost savings from wage differentials exists yet continues to be elusive. As the wages of offshore developers continues to rise, these savings become even more elusive. Research by the McKinsey Global Institute (MGI) finds that billions of dollars of savings are not being realized by companies who offshore and recommend "a total transformation of business processes to harness the new environment's potential". Reorganizing and reengineering operations to take full advantage of wage differentials opens up a variety of other opportunities that will ultimately boost revenue growth and exceed the annual cost savings (Agrawal et. al., 2003).

\section{PRIOR OFFSHORING STUDIES}

Offshoring research from trade sources is concerned with the actual offshoring decision, the magnitude and future trends of offshoring, the political consequences, and whether offshoring was a failure or success for particular companies. Survey research from trade sources also attempts to determine the proper way to do offshoring. The problem is that offshoring is generally treated as something that exists in one form, not many. Although clientvendor relationship advice is often given or surveyed, different types of offshoring based on the client-vendor relationship are not acknowledged. Relationship advice is given as if it applies to all offshoring ventures equally. These findings point to an increasing trend in offshoring despite mixed findings regarding economic, political, and strategic benefits and the success rate of offshoring ventures. Spurring this study are the all too often lackluster economic and strategic benefits of offshoring, contradictory how-to advice on maintaining a client-vendor relationship, and the low success rates of offshoring being reported by numerous trade sources. Rather than examining economic and strategic measures of offshoring success, the focus of this study is on the client-vendor relationship and its association to offshoring success. Previous research on the offshoring client-vendor relationship has been primarily case studies, literature reviews, and opinion articles. In his 2004 comprehensive survey and analysis of the outsourcing literature, Dibbern concluded that there was a "relative lack of research directed towards an examination of the relationship between the outsourcer and the customer" and that although several studies comment on the importance of the relationship, there is a relative lack of positivist research examining and analyzing that relationship. This scant research becomes even more lacking when the outsourcing relationship is restricted only to offshoring relationships.

\section{OUTSOURCING, OFFSHORING AND TRUST}

Outsourcing and offshoring are terms that have sometimes been used interchangeably in the literature to refer to an arrangement by which a company turns over some IT functions to another company. However, for the purposes of this paper, outsourcing and offshoring are two separate terms having two distinct meanings. Outsourcing and offshoring are similar concepts, but findings from outsourcing studies are not necessarily generalizable to offshoring. Rottman and Lacity (2004) identified the twenty best outsourcing practices and later repeated the study to identify the twenty best offshoring practices. They found that ten practices were more important for offshoring, five practices only applied to offshoring, and only five practices were considered best practices for both outsourcing and offshoring. In addition to distance, time, and cultural issues, one of the most obvious differences between outsourcing and offshoring is the disparity in labor costs, estimated to be a savings of around $30 \%$ after accounting for the costs and risks of offshoring. Outsourcing vendors located in the same country as the client cannot gain from differential labor costs in the same way as an offshore vendor (Weber, 2004).

Outsourcing has been referred to as the practice of turning over an organization's IT functions, in whole or in part, to an external service provider (Grover et. al., 1996). Two types of outsourcing identified by Palvia, based on relative location from the client, are shore and offshore (2005). Shore outsourcing refers to information technology development that is turned over to an external vendor within the client's country of origin, while offshore outsourcing, or simply offshoring, means the external vendor is located in a country other than the client's country. The workers in vendor countries like India are more sophisticated and educated than they were and in greater numbers. As previously discussed, the amount of work being offshored has rapidly, steadily, and publicly increased. Less noticeable is that the nature of the IT work being offshored is suddenly quite different. The call centers are still there, but the new trend is to offshore more complex and critical work. These changes in what is 
being offshored follow changes in the reasons client companies are offshoring. All of these changes are only possible because of changes in technology, particularly increased bandwidth. It can only be expected that these changes affect the nature of offshoring relationships between clients and vendors. These relationships are becoming more complex as offshoring increases and involves more sophisticated, strategic work.

Economic theories have been used to examine the outsourcing or offshoring decision, particularly the offshoring decision with its prominent differential labor cost factor. The economic downturn of the late 1990s highlighted the importance of cost savings and the appropriateness of using economic theories. Cost savings was recognized as one of the primary determinants for a company to choose an offshoring model along with economies of scale and access to specialized resources (McFarlan and Nolan, 1995). Cost factors remain an important consideration. As offshoring has grown and the number of companies and countries providing offshoring vendor services has grown, competition between vendor companies and countries has increased (Rajkumar \& Mani, 2001). Additionally, King (2005) recognizes that a model based on cost factors alone is no longer appropriate for making outsourcing decisions because of a new trend in offshoring higher-end activities, such as developing sophisticated software for analysis, data mining and process modeling. Many outsourcing failures are attributed to the failure of relationships, specifically the lack of trust between vendor and client (Rajkumar \& Mani, 2001). Grover et al (1996) identified trust as a significant factor associated with laying a basis for building a relationship. Trust was also found to be a significant factor in managing an ongoing relationship. Trust in inter-organizational exchanges (for example, offshoring) is linked to performance and clearly matters. In higher commitment client-vendor relationships, trust rather than incentives and penalties - becomes an important mechanism to ensure that the vendor's interests coincide with the client's interests (Kishore et al, 2003).

\section{CONCLUSIONS}

Offshoring today is different than it was yesterday; specifically, client-vendor relationships need to be closer and more flexible. Early offshoring consisted of simple outsourcing contracts involving straight-forward simple tasks along the lines of call centers, help desks and simple software maintenance. Gradually, simple software maintenance became ever more sophisticated software development. As the education and sophistication level of foreign software developers increased, offshoring increased in volume and involved more sophisticated development. New technologies that increased bandwidth and the ability to offshore new and more complicated processes further increased the volume and sophistication of offshoring work. At the same time, competition between client companies to obtain the services of vendor companies and increasing wages of foreign software developers has switched the primary focus and benefit of offshoring from one of cost savings to one of strategic importance.

The social aspects of the relationships have become more important than the contractual (written or unwritten) relationship. Client companies are now offshoring for strategic reasons - to improve competitive advantage rather than simply reduce costs. Though the offshoring trend continues at a phenomenal rate, the success rate of offshoring ventures does not. Changes in both the complexity and nature of work being offshored, as well as the mixed results of offshoring ventures, justify a new and closer examination of the client-vendor relationship.

\section{AUTHOR INFORMATION}

Jeremy St. John is an Assistant Professor of Management Information Systems at Texas A\&M UniversityCommerce. He received his Ph.D. from the University of North Texas. His research interests include information technology offshoring, process virtualization, and supply chain management.

Richard G. Vedder is a Professor of Information Systems at the University of North Texas. He received his Ph.D. from the University of Arizona. His research interests include multimedia systems, knowledge-based systems, impact of new technologies and competitive intelligence. He has published articles in Decision Sciences, Communications of the ACM, Computers and Society, IEEE Transactions on Systems, Man and Cybernetics, Expert Systems, and Journal of Information Systems Management. 
C. Stephen Guynes is a Regents Professor of Information Systems at the University of North Texas. He received a doctorate in quantitative analysis from Texas Tech University. Dr. Guynes' areas of specialization are client/server computing, end-user computing, data administration, and information resource management. His most recent research efforts have been directed in the areas of client/server computing and data administration. Some of the journals in which Dr. Guynes has published include Communications of the ACM, Information \& Management, The Journal of Information Systems Management, Journal of Accountancy, Journal of Systems Management, The Journal of Database Management, The CPA Journal, The Journal of Computer Information Systems, Information Strategy, Computers and Security, and Computers and Society. E-mail: Guynes@unt.edu (Corresponding author)

\section{REFERENCES}

1. Agrawal, V., Farrell, D., \& Remes, K. (2003). Offshoring and beyond: Cheap labor is the beginning, not the end. The McKinsey Quarterly, 4.

2. Aron R., \& Singh, J. (2005). Getting offshoring right. Harvard Business Review 83, 135-147.

3. Blinder, A. (2006). Offshoring: The Next Industrial Revolution? Foreign Affairs, 85 (2).

4. Dibbern, J., Goles T., Hirschheim R., \& Jayatilaka B. (2004). Information systems outsourcing: A survey and analysis of the literature. Database, 35(4), 6-102.

5. Grover, V., Cheon, M.J., \& Teng, J.T.C. (1996). The effect of service quality and partnership on the outsourcing of information systems functions. Journal of Management Information Systems, 12(4), 89116.Kaiser, K. M., \& Hawk, S. (2004). Evolution of offshore development: from outsourcing to cosourcing. MISQ Executive, 3(2).

6. King, W. (2005). Outsourcing becomes more complex. Information Systems Management, www.ISMJournal.com

7. Kishore, R., Rao H.R., Nam K., Rajagopalan S. \& Chaudhury A. (2003). A relationship perspective on outsourcing. Communications of the ACM, 46(12) 87-92.

8. McFarlan, W. F., \& Nolan, R. L. (1995). How to manage an IT outsourcing alliance, Sloan Management Review, 36(2), 9-23.

9. Palvia, P.C. (2005). Outsourcing issues and challenges facing CEOs and CIOs. Journal of Information Technology Case and Application Research, 7(4).

10. Phannenstein, L., \& Tsai, R. (2004). Offshore outsourcing: current and future effects on American IT industry [Electronic version]. Information Systems Management, 21(4), 72-80.

11. RajKumar, T.M., \& Mani, R.V.S. (2001). Offshore software development: The view from Indian suppliers. Information Systems Management, 18(12), 62-72.

12. Rottman, Joseph W. \& Lacity, M. C., (2004). Twenty practices for offshore outsourcing, MISQ Executive, (September), 3(3).

13. Weber R. (2004). Some implications of the Year-2000 era, dot-com era and offshoring for information systems pedagogy. MIS Quarterly, 28(2), iii-xi. 